Copyright by the American Society of Agricultural and Biological Engineers. Wade, C. R.; Bolding, M. C.; Aust, W. M.; Lakel, W. A.; Schilling, E. B., "Comparing sediment trap data with the USLE-forest, RUSLE2, and WEPP-road erosion models for evaluation of bladed skid trail BMPs," Transactions of the ASABE. 55(2): 403-414. (doi: 10.13031/2013.41381) @2012

\title{
COMPARING SEDIMENT TRAP DATA WITH THE USLE-FOREST, RUSLE2, AND WEPP-ROAD EROSION MODELS FOR EVALUATION OF BLADED SKID TRAIL BMPS
}

\author{
C. R. Wade, M. C. Bolding, W. M. Aust, W. A. Lakel III, E. B. Schilling
}

\begin{abstract}
Three erosion models, the Universal Soil Loss Equation for Forestry (USLE-Forest), the Revised Universal Soil Loss Equation Version 2 (RUSLE2), and the Water Erosion Prediction Project for Forest Roads (WEPP-Road), were compared to sediment trap data for bladed skid trail best management practices (BMPs). The bladed skid trail BMPs evaluated were: (1) water bar only (control treatment); (2) water bar + lime, fertilizer, and grass seed (seed treatment); (3) seed + straw mulch (mulch treatment); (4) control + piled hardwood slash (hardwood slash treatment); and (5) control + piled pine slash (pine slash treatment). This study used three erosion models to evaluate the BMPs while also using linear regression, model efficiency (NSE), and percent bias (PBIAS) to compare the prediction accuracy and applicability of the models to monthly erosion collected in sediment traps from six replications of the five treatments. Results showed significant treatment differences due to the BMPs, with the control treatment being the most erosive, followed generally by the seed, hardwood slash, pine slash, and mulch treatments. Model predictions indicated that all models were suitable for ranking erosion rates for the skid trail closure treatments for simple hazard or BMP ratings. However, the older and simpler USLE-Forest and RUSLE2 models had satisfactory NSE and PBIAS values, whereas WEPP-Road did not. Results indicate that WEPP-Road needs additional enhancement with regard to skid trail parameters before it can be effectively used for erosion prediction on bladed skid trails.
\end{abstract}

Keywords. Bladed skid trails, Erosion, Soil erosion models.

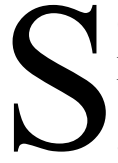
ediment is the largest type of nonpoint-source pollution (NPSP) in the U.S. (USEPA, 2003). Sedimentation derived from land uses such as agriculture, forestry, urban development, and atmospheric deposition are the leading sources of NPSP (Yoho, 1980, Neary et al., 1989). In response to the erosion potential from silvicultural operations, forestry best management practices (BMPs) have been developed to prevent or minimize potential erosion-related problems (Ice et al., 2010). Forestry BMPs focus on highly disturbed areas within a silvicultural system that are prone to erosion, such as roads, logging decks, and skid trails (Aust and Blinn, 2004; Anderson and Lockaby, 2011). These disturbed areas have been shown to typically represent approximately $2 \%$ to $10 \%$ of the total harvested area (Rice et al., 1972; Kochenderfer, 1977), although poorly planned

Submitted for review in December 2010 as manuscript number SW 8966; approved for publication by the Soil \& Water Division of ASABE in February 2012.

The authors are Charlie R. Wade, former Graduate Research Assistant, M. Chad Bolding, ASABE Member, Assistant Professor, and W. Mike Aust, Professor, Department of Forest Resources and Environmental Conservation, Virginia Tech, Blacksburg, Virginia; William A. Lakel III, Water Quality Program Supervisor, Virginia Department of Forestry, Charlottesville, Virginia; and Erik B. Schilling, ASABE Member, Senior Research Scientist, National Council for Air and Stream Improvement, Southern Regional Center, Newberry, Florida. Corresponding author: M. Chad Bolding, Department of Forest Resources and Environmental Conservation, 228 Cheatham Hall, Virginia Tech, Blacksburg, VA 24061; phone: 540-231-6924; e-mail: bolding @vt.edu. harvests have been found to result in $25 \%$ trail coverage (Jackson et al., 2001).

BMPs are designed to reduce erosion by decreasing the amount and velocity of overland flow, thus decreasing the erosive energy and maintaining soil stability. Common BMPs used for roads, skid trails, and logging decks include: (1) proper planning, construction, and location; (2) control of grade; (3) control of water; (4) surfacing; and (5) road or trail closure (Swift, 1985; Swift and Burns, 1999; Aust and Blinn, 2004; Grace, 2005a). Bladed skid trails are low standard forest roads that are commonly used to access timber with ground-based skidders on sites having sideslopes that limit overland skidding (Garland, 1997). Bladed skid trail closure is important because skid trails are typically built to lower standards than haul roads and have the potential to be a greater source of sediment (Grushecky et al., 2009). Typical trail closure BMPs include installing water bars and seeding but may or may not include the addition of straw mulch or other cover (Grace, 2002; Aust and Blinn, 2004) due to operational challenges or prohibitive BMP implementation cost incurred by loggers (Bolding et al., 2010).

Typical erosion rates experienced by roads and trails can range between 10 to $100+$ tonnes ha ${ }^{-1}$ year $^{-1}$ (Kochenderfer and Helvey, 1987). McGreer (1981) monitored erosion on skid trails established on volcanic ash soils in Idaho with varying degrees of slope, and the results indicated that erosion rates increased as subsoil was exposed and slopes increased. Trails established on $40 \%$ slopes with subsoil exposed had erosion rates as high as 163 tonnes ha ${ }^{-1}$ year $^{-1}$. 
Direct measurement of soil erosion is an expensive research methodology because of the time and effort necessary for such collections (Robichaud and Brown, 2002). Thus, soil erosion models have been developed to predict erosion rates from both hillslopes and roads ( $\mathrm{Fu}$ et al., 2010). Erosion prediction methods are also used to evaluate management practices and erosion control techniques (Elliot, 2004) and provide a cost-effective and time-efficient way to evaluate the performance of forestry BMPs (Fu et al., 2010). $\mathrm{Fu}$ et al. (2010) evaluated seven commonly used erosion models for forest roads and subdivided the models into empirical and physically based models. Empirical models include widely known and applied models such as the Universal Soil Loss Equation (USLE; Wischmeier and Smith, 1965) and USLE-derived models (USLE-Forest; Dissmeyer and Foster, 1984) and the Revised USLE (RUSLE; Renard et al., 1991). Empirical models are based on the statistical relationships between independent variables and sediment. Physically based models such as the Water Erosion Prediction Project (WEPP; Elliott et al., 1999) and WEPP for forest roads (WEPP-Road; Elliot, 2004) are based on hydrologic and soil processes. Physically based models typically require considerable inputs (Merrit et al., 2003). Fu et al. (2010) concluded that empirical models were less adaptable to a wide range of conditions but were more likely to be used by land managers due to their fewer input parameters. Conversely, physically based models were more adaptable to a wider range of conditions but are primarily used by researchers rather than land managers. Croke and Nethery (2006) supported the concept that the more complex WEPP model is better suited to erosion estimates for research purposes, whereas the simpler USLE is better suited for identification of erosion hazards by land managers. Christopher and Visser (2007) specifically proposed a methodology for using USLE-Forest for aiding in BMP inspections.

USLE was originally designed to predict erosion rates from agricultural lands but has since been adapted to predict erosion from forested lands (USLE-Forest; Dissmeyer and Foster, 1984). USLE was not developed for use on road and trail surfaces, but numerous researchers have used it to evaluate forest roads (Megahan et al., 2001; Hood et al., 2002; Sheridan et al., 2006) as well as construction site BMPs (Moore et al., 2007; Tyner et al., 2011). The Revised Universal Soil Loss Equation (RUSLE) uses the same process of predicting erosion rates as USLE but requires additional input variables (Renard et al., 1991). RUSLE was released in the early 1990s and has evolved into the current RUSLE version 2 (RUSLE2), which was released in 2003 (Foster et al., 2003). WEPP is a physically based, continuous simulation erosion model that was originally designed to estimate erosion from agricultural hillslopes (Fu et al., 2010). WEPP has been modified for forest applications, and WEPP-Road was specifically intended for erosion estimates from forest roads and allows features such as road surface, ditches, cut-fill slopes, and vegetation to be included (Dun et al., 2009). WEPP has been widely used for forest road erosion studies (Elliot et al., 1995, 1999; Rhee et al., 2004; Croke and Nethery, 2006; Forsyth et al., 2006).
Tiwari et al. (2000) compared the model efficiencies of USLE, RUSLE, and WEPP with field-measured erosion data in an agricultural research project. Their results indicated that USLE had the best performance, but all three models had acceptable efficiency values $(>0.70)$. Laflen et al. (2004) performed a similar study and concluded that USLE has utility, but WEPP has advantages on a broader range of conditions. Croke and Nethery (2006) compared USLE and WEPP model predictions of soil erosion with field data in Australian forests. The USLE and WEPP models worked well for skid trails, but neither worked as well for less disturbed areas. Moore et al. (2007) used WEPP for estimating soil erosion on construction sites in North Carolina. This research found that WEPP could produce satisfactory agreement with actual erosion data after several parameters had been modified, but also suggested that additional field validations should be performed. Amore et al. (2004) compared the USLE and WEPP models in three Sicilian watersheds. Their research indicated that the WEPP model estimates corresponded more closely with actual erosion than did the USLE model.

Overall, the literature indicates that the empirical erosion models (e.g., USLE, RUSLE) require fewer input parameters than the physically based models and can be used to model erosion suitably well for comparing BMPs or identifying erosion hazards. More complex physical models (e.g., WEPP) require more input parameters but appear to work suitably on a wide range of sites, including North America (Elliot et al., 1995), South America (Cecilo et al., 2004), Europe (Amore et al., 2004), and Australia (Yu and Roswell, 2001). This versatility makes WEPP more desirable for research or landscape planning. Thus, the empirical models may be better suited for simple BMP inspections, while WEPP may be better suited for largescale planning and watershed research.

\section{STUDY OBJECTIVES}

This study is part of a larger research project. The larger project was developed to evaluate the effectiveness of different BMP treatments on erosion from bladed skid trails, and these data are reported by Wade (2010) and Wade et al. (2010, 2011, 2012). The goal of this study was to evaluate the accuracy of three erosion models by comparing model simulation results with erosion measurements from sediment traps. The models evaluated were the Universal Soil Loss Equation for Forestry (USLE-Forest; Dissmeyer and Foster, 1984), the Revised Universal Soil Loss Equation version 2 (RUSLE2; Toy et al., 1999), and the Water Erosion Prediction Project for Forest Roads (WEPP-Road; Elliot, 2004). Five closure and cover BMPs for bladed skid trails were evaluated by direct measurement (sediment traps) and by use of the models. The closure and cover BMPs evaluated were: (1) water bar only (control treatment); (2) water bar, lime, fertilizer, and grass seed (seed treatment); (3) seed and straw mulch (mulch treatment); (4) control and piled hardwood slash (hardwood slash treatment); and (5) control and piled pine slash (pine slash treatment). Model accuracy was determined by comparing the erosion estimates made by the models to the monthly erosion rates measured in sediment traps during one year. 


\section{MATERIALS AND MethodS}

\section{STUDY SITE}

This study was conducted at the Reynolds Homestead Forest Research and Extension Center in Patrick County, Virginia, in the upper Piedmont physiographic region. Typical temperatures range from $-1.8^{\circ} \mathrm{C}$ to $9^{\circ} \mathrm{C}$ in January and from $17.8^{\circ} \mathrm{C}$ to $29.7^{\circ} \mathrm{C}$ in July. The average precipitation is $167.1 \mathrm{~cm}$, with $138.2 \mathrm{~cm}$ being rainfall and the remaining $28.9 \mathrm{~cm}$ being snowfall (Patrick County, 2012). The treatments were installed in a 5 ha clearcut with side slopes of $15 \%$ to $20 \%$. The dominant soil series on the site is Fairview (sandy clay loam, fine, kaolinitic, mesic Typic Kanhapludults). This soil is formed from residuum from mica schist and mica gneiss, is very well drained, and has an erodibility index of 0.28 (NRCS, 2009).

Gradelines were located with a clinometer and flagged. Trails were constructed with a John Deere 450e bulldozer with slopes ranging between $10 \%$ and $20 \%$, which complies with the Virginia Department of Forestry recommended BMPs (VDOF, 2011). All trails were approximately $76 \mathrm{~m}$ in length, and five treatments on each trail measured approximately $15.2 \mathrm{~m}$ in length and $3 \mathrm{~m}$ in width. The slopes of each trail were constant, so the locations of the BMP treatments on each trail were randomly assigned, and each trail was considered a block within a randomized complete block design (fig. 1). The six replications of the five treatments provided thirty trail segments. Water bars were constructed at the top and base of each treatment segment to ensure that only sediment generated within the treatment was measured. Sediment was captured at the base of the treatments in a system of gutters and Dirtbag sediment traps (ACF Environmental, Richmond, Va.).

\section{BMP TREATMENTS}

The control treatment consisted of only water bars and represented the minimal-closure BMP commonly recommended in the eastern U.S. (Aust and Blinn, 2004). Water bars were built 0.6 to $0.9 \mathrm{~m}$ in height and installed at $45^{\circ}$ from treatment slopes with a John Deere 450e bulldozer.

The seed treatment consisted of water bars plus application of lime (2.3 tonnes $\left.\mathrm{ha}^{-1}\right), 10-10-10$ fertilizer $\left(227 \mathrm{~kg} \mathrm{ha}^{-1}\right.$ ), and grass seed (approx. $300 \mathrm{~kg} \mathrm{ha}^{-1}$ ). Seed was applied at the maximum recommended rate to ensure

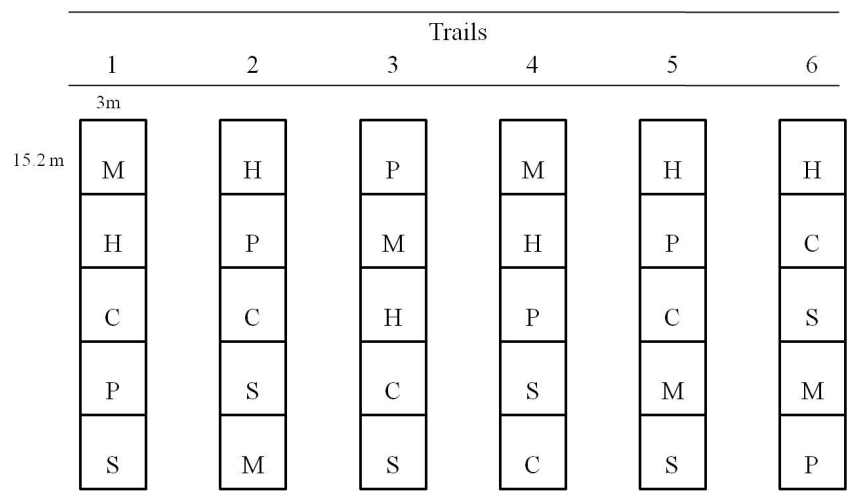

Figure 1. Idealized treatment layout for the randomized complete block design for bladed skid trails: $\mathrm{C}=$ control, $\mathrm{S}=$ seed, $\mathrm{M}=$ mulch, $\mathbf{H}=$ hardwood slash, and $\mathbf{P}=$ pine slash. establishment, and was reapplied on treatments where germination and establishment was less than 40\%. All applications were made with a hand-crank applicator.

The mulch treatment consisted of the seed treatment plus straw mulch. The application of seed, lime, and fertilizer was the same as in the seed treatment. Straw (approx. 8 tonnes $\mathrm{ha}^{-1}$ ) was hand-applied at a rate that initially gave nearly $100 \%$ coverage. This application rate is basically equivalent to two bales of straw for each mulch treatment.

The hardwood slash treatment consisted of the control plus an application of piled hardwood slash. Slash ranged from 2.5 to $15.2 \mathrm{~cm}$ in diameter and 1.2 to $3 \mathrm{~m}$ in length. Slash was piled to a depth of 1 to $1.25 \mathrm{~m}$ in treatments using a front-end loader on an agricultural tractor. Subsequently, hardwood slash was trafficked into contact with the soil by a JD 450e bulldozer to ensure adequate ground contact.

The pine slash treatment consisted of the control plus an application of piled pine slash. Pine slash was piled to a depth of approximately $1 \mathrm{~m}$. The lengths and diameters of the pine slash were similar to the hardwood slash, and the application and tracking procedures were the same.

Sediment trap weights were measured monthly and are reported by Wade (2010) and Wade et al. (2010, 2011). Each of the 30 treatment areas were measured monthly for 13 months, creating a total data set of 390 measurements ( 6 blocks $\times 5$ treatments $\times 13$ months $)$. All sediment trap weights were corrected for soil moisture, bag moisture, and sediment trap efficiency.

\section{Erosion Model Parameters}

Erosion model data included climatic factors, soil factors, cover and management characteristics, and slope and length measurements. Treatments were divided into two segments, estimates were made for each segment, and weighted averages (based on area) of segments were used to determine the final predicted erosion rates per treatment. Generalized slope values were used for USLE-Forest estimates (fig. 2), while more detailed profiles were used for RUSLE2 and WEPP-Road estimates (fig. 3).

\section{USLE-FOREST}

The USLE-Forest estimates of erosion are based on the following equation:

$$
A=R \times K \times L S \times C P
$$

where $A$ is erosion per unit area per time period, $R$ is the rainfall runoff factor, $K$ is the soil erodibility factor, $L S$ is the slope steepness and slope length factor, and $C P$ is the cover and management practice factor (Dissmeyer and Foster, 1984). A rainfall and runoff factor $(R)$ of 175 was derived from the isoerodent map provided in the USLEForest manual (Dissmeyer and Foster, 1984) for the Reynolds Homestead location. A soil erodibility factor $(K)$ of 0.28 was obtained from the Patrick County Soil Survey (NRCS, 2009) for the subsoil of the Fairview series. Slope percent $(S)$ and length $(L)$ profiles of the treatment areas were measured with a total station. Values for the $L S$ factor were obtained from the USLE-Forest manual (Dissmeyer 


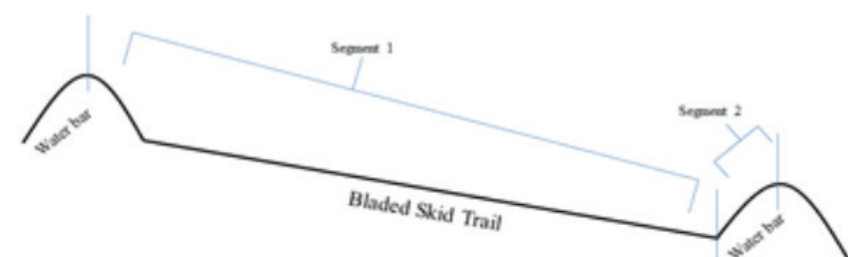

Figure 2. Division of treatments into two separate segments for use in USLE-Forest. Slope values for segment 1 were the percent slope from the top of the water bar at the head of the treatment to the base of the water bar at the foot of the treatment, and the slope length was the distance between. The slope for segment 2 was the percent slope of the backslope of the water bar at the foot of the treatment, and the slope length was the length of the backslope.

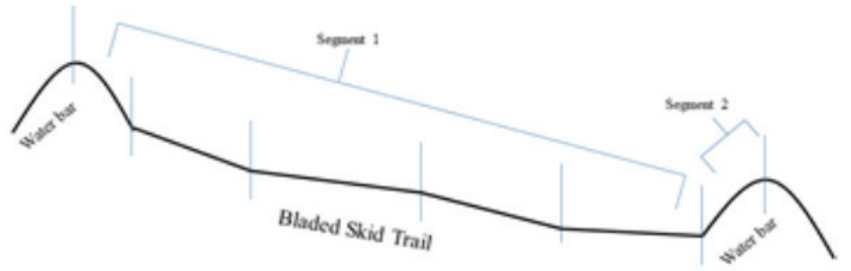

Figure 3. Division of treatments into two separate segments for use in RUSLE2 and WEPP-Road. Segment 1 is more detailed and based on the slope and distance data collected at multiple locations. The slope for segment 2 was the percent slope of the backslope of the water bar at the foot of the treatment, and the slope length was the length of the backslope.

and Foster, 1984). Slope percent and slope length values were segmented from: (1) the top of the upslope water bar of the treatment to the base of the downslope water bar, and (2) from the top of the downslope water bar to the foot of the treatment (fig. 2). Slope lengths for the second segment were too small to be found in the USLE-Forest handbook's tables; thus, the following equation was used to calculate these values:

$$
L S=(\lambda / 72.6)^{m}\left(65.41 \sin ^{2} \theta+4.65 \sin \theta+0.065\right)
$$

where $\lambda$ is the slope length (feet), $\theta$ is the slope angle (degrees), and $m$ is 0.2 for $<1 \%$ slopes, 0.3 for $1 \%$ to $3 \%$ slopes, 0.4 for $3.5 \%$ to $4.5 \%$ slopes, and 0.5 for $\geq 5 \%$ slopes (Dissmeyer and Foster, 1984).

Due to the topsoil disturbance and traffic effects, the bladed skid trails were considered a tilled soil. $C P$ subfactors for a tilled soil include: (1) bare soil, residual binding, and soil reconsolidation; (2) canopy effect; (3) steps; (4) onsite storage; (5) invading vegetation; and (6) contour tillage. The bare soil, residual binding, and soil reconsolidation subfactor was estimated along transects on the treatment slope. Four transects, which were perpendicular to the slope and spaced at $3.7 \mathrm{~m}(12 \mathrm{ft})$ intervals along the treatment slope, were established, and measurements were collected at $0.3 \mathrm{~m}(1 \mathrm{ft})$ intervals along the transects. Three of these transects were in segment 1 and the fourth transect was in segment 2 , according to the segment descriptions in figure 2 . At each $0.3 \mathrm{~m}$ point, the ground was classified as either covered or not. Percent bare soil was then calculated for each transect. The remaining $C P$ subfactors were estimated for the entire treatment.

Erosion rates were calculated for each transect using the percent bare soil estimate and the remaining variables. This provided a total of three erosion rates for segment 1 and one erosion rate for segment 2 . The erosion rates of the transects in segment 1 were averaged together to determine an erosion rate for the segment. The area in each segment was used to provide a weighted average of the total erosion rate per treatment.

The USLE-Forest measurements for prediction were collected during four seasons (summer, fall, winter, and spring) during the course of the study. A weighted average was used at the end of the study period to determine a final erosion rate per treatment. Initially, both the seed and mulch treatments had bare soil and grassed phases. During the grass establishment period, both pre- and post-grass establishment values were collected. For the seed and mulch treatments, erosion values were adjusted based on the length of time that was required for grass establishment.

\section{RUSLE2}

Erosion estimates using RUSLE2 were conducted in a similar manner as with the USLE-Forest estimates. Treatments were divided into two segments, and a weighted average of both segments provided a total erosion estimate per treatment. However, RUSLE2 allows for a more detailed slope profile, with multiple sections (Toy et al., 1999). Elevation data were collected at multiple spots along the treatment slope, and these data were used to create profiles in the model, where segment 1 incorporated five sections and segment 2 had only one (fig. 3). Estimates were made for a one-year model run.

First, climate data were accessed from the NRCS and ARS database (NRCS, 2009) for Patrick County, Virginia, and included average daily and monthly values of rainfall and temperature. Second, a soil file can either be downloaded from the RUSLE2 database or created for sitespecific conditions. Within the soil file, there is information on the texture of the soil, erodibility index, consolidation period, and acceptable soil loss rates. The study soil was a Fairview sandy clay loam, and a soil file pertaining to this classification was downloaded for analysis. Third, slope files were created for each experimental unit based on measured slope and distance. The final component was a management file that described surface conditions. Within the software, there are management files that have already been developed for certain activities. The user can use these files or create new ones for conditions that are not covered in the database. Management files were created in the following way for treatments.

Within the RUSLE2 database, there are no files specific to forest roads. To develop a file for the water bar only (control) treatment, the "highly disturbed land/blade cut" option was modified. The "highly disturbed land/blade cut" option was used to simulate the cutting and removal of topsoil that occurs when bladed skid trails are constructed. Next a "highly disturbed land/track walking" operation was implemented to mimic the effects that dozer tracks would have on the slope. The date of operation was set to June 1 of year 1 for both operations. This date coincided with the approximate date of trail installation.

The management file for the seed treatments used the 
file created for the control treatment as the base template, and a "broadcast seed operation" applying a "southern range grass May 15" was added. This seed application most closely resembled the actual seeding operation. The date of application was set to June 1 of year 1 .

The management file for the mulch treatments was created by adding a mulch addition to the seed treatment management file. The mulching operation was called "highly disturbed land/add mulch." This mulching operation allows the user to choose from a variety of mulching agents. The type of mulch applied in this study was "wheat straw." Within this operation, the user is allowed to set the application rate in weight per unit area. Depending on the application rate, RUSLE2 estimates the amount of coverage provided. In the field-based portion of the study, straw mulch was applied at a rate of 7.9 tonnes ha ${ }^{-1}$, which gave approximately $100 \%$ coverage initially. An application rate of 10.1 tonnes $\mathrm{ha}^{-1}$ was required to achieve this coverage in RUSLE2.

The RUSLE2 database does not have management files that are designed for woody slash residue additions. The most similar file is an addition of "wood fiber" as a mulching agent. However, the "wood fiber" is treated as small chip-sized pieces that have a relatively short decomposition half-life of 35 days. Alterations to this file were made to better represent the slash treatments. The control treatment management file was used as the template, and a mulching operation was performed with "wood fiber" as the mulching agent. To mimic the treatments using large woody debris, some adjustments to the "wood fiber" were made. The response of the residue was changed from "fragile very small" to "woody large." For the hardwood slash treatments, the decomposition halflife was changed to 1800 days based on the decomposition rates published by Onega and Eickmeier (1991) for woody debris and boles in southern Appalachian deciduous hardwood forests. Pine decomposition rates were based on the findings of Barber and Van Lear (1984) for loblolly pine (Pinus taeda). Based on their results, a half-life decomposition rate of ten years (approx. 3700 days) was used to model the decomposition of pine slash in the pine slash treatments. Cover provided by the slash was based on the cover data collected during the USLE-Forest data collection. An average of the cover values from the top three transects was taken to get a coverage value for segment 1. The fourth transect was used for cover values for segment 2 .

\section{WEPP-ROAD}

WEPP-Road requires four types of files to make predictions (slope characteristics, climate, soil characteristics, and land cover characteristics). Embedded within the software are generic files for each of the four types that the user can use or alter to create new site-specific files. Erosion estimates were based on model runs of one year.

Slope files were created in WEPP-Road similarly to the way they were created in RUSLE2. Segment 1 incorporated five sections, with varying slope and length, and segment 2 incorporated only one section (fig. 3).

WEPP-Road has an attached database of CLIGEN parameter files; however, there was no parameter file specific to the Reynolds Homestead Forest Research and Extension Center. The nearest weather station with a CLIGEN parameter file is Philpott Dam, Virginia, approximately $16 \mathrm{~km}$ (10 miles) to the northeast. A CLIGEN parameter file was created using the "Add Climate Location" function in WEPP-Road. This function allows the user to pinpoint the location on a map, and WEPP-Road searches the surrounding area for any weather stations that have associated CLIGEN files. WEPP-Road then interpolates the data from these stations to produce a unique file for a particular area. Prior to creating the CLIGEN file, WEPP-Road shows the user the values for average monthly maximum temperature, average monthly minimum temperature, average precipitation on wet days, the probability of a wet day following a wet day, the probability of a wet day following a dry day, solar radiation, maximum $30 \mathrm{~min}$ intensity, time to peak intensity, and average monthly dewpoint temperature. The user can either accept these values or replace them with site-specific values. Once this is complete, a file is created that can be used in CLIGEN to create climate data.

A total of 19 weather stations were used to create a CLIGEN parameter file for the Reynolds Homestead Forest Research and Extension Center. The closest weather station was approximately $16 \mathrm{~km}$ (10 miles) away, and the farthest was approximately $103 \mathrm{~km}$ (64 miles) away. Site-specific data on average monthly maximum temperature, average monthly minimum temperature, solar radiation, and average monthly dewpoint temperature were available. Therefore, these data were used instead of the interpolated data. The resulting CLIGEN parameter file was used in the analysis.

Within the WEPP-Road soils database, the most similar soil file to a Fairview sandy clay loam was the "Disturbed Skid Clay Loam," which was used in the analysis. WEPPRoad includes management files, some of which were used unaltered while others were changed in the following ways to more closely resemble the installed treatments.

Since WEPP-Road was also designed for erosion estimates on roads, it has a management file for forest roads called "Forest Bladed Road." This file was used for the control treatments.

For the seed treatments, the initial conditions were set to the "Forest Bladed Road," and then "annual ryegrass at a medium fertilization rate" was used. In order to mimic the annual nature of the grass, the senescence parameters were altered. The percent growing season when leaf area index (LAI) declines was accepted at its default value of $85 \%$, the period over which senescence occurs was accepted at the default value of 14 days, the canopy remaining after senescence was changed to $50 \%$, and the biomass remaining was also changed to $50 \%$. The date of grass seed application was set to five days after construction.

Mulch treatment management files were created by using the file created for the seed treatment and then adding fescue residue as mulch at a rate of $0.788 \mathrm{~kg} \mathrm{~m}^{-2}$. This value equates to roughly $36.3 \mathrm{~kg}$ per treatment, which is the amount of straw mulch applied in the field portion of the study.

There are no management files within the WEPP-Road 
database that use woody debris as mulch. New files had to be created for both the hardwood and pine slash treatments. Since there were no residue additions that resembled hardwood or pine slash, these treatments were modeled by applying fescue mulch. The control management file was used as the base template, and fescue mulch was applied. In RUSLE2, the coverage provided by the mulch could be used for the application rate; however, WEPP-Road does not give the user that option. In WEPP-Road, the actual weight per unit area is used. The application rate actually applied to the slash treatments in the field was used.

\section{Data AnAlysis}

Treatment effects for each erosion model (six replications of five treatments) were determined by analyzing the model predictions in SAS v9.2 (SAS, 2008) as a randomized complete block design using the PROC GLM procedure. Significant differences of treatment effects were based on alpha levels of 0.05. Subsequent mean separations of significantly different treatments were based on Tukey means separation tests.

Erosion model estimates were also compared to sediment trap erosion rates to evaluate model accuracy and applicability. Linear regression analyses were used to compare erosion model estimates to the corresponding sediment trap erosion rates. Normal probability plots revealed that the predicted erosion values for the models were not normally distributed; thus, logarithm transformations were performed on the data used for regression. All statistical analyses related to the regressions were based on the transformed data.

Model performance was evaluated based on the linear regression diagnostic correlation coefficient and the use of the Nash and Sutcliffe (1970) model efficiency (NSE) and percent bias (PBIAS) (Moriasi et al., 2007). NSE was calculated as follows:

$$
\mathrm{NSE}=1-\frac{\sum_{i=1}^{n}\left(Q_{o} i-Q_{p} i\right)^{2}}{\sum_{i=1}^{n}\left(Q_{o} i-\bar{Q}_{o}\right)^{2}}
$$

where $Q_{o} i$ is the actual sediment trap erosion rate, $Q_{p} i$ is the erosion rate predicted by the erosion model, $\bar{Q}_{o}$ is the mean of the sediment trap erosion rates, and $n$ is the number of observations $(n=30)$. This measure of efficiency is somewhat analogous to the correlation coefficient (r) from linear regression; however, it compares the sediment trap rates to the 1:1 line of sediment trap rates equal to model predictions rather than to the best fit regression line. NSE not only considers the linearity of the data but also the relative differences between the measured and predicted values (Risse et al., 1993). Based on the recommendations of Moriasi et al. (2007), NSE values of $>0.5$ were assumed to indicate satisfactory performance.

Percent bias (PBIAS) is calculated as:

$$
\text { PBIAS }=\frac{\sum_{i=1}^{n}\left(Y_{i}^{o b s}-Y_{i}^{s i m}\right) \times 100}{\sum_{i=1}^{n}\left(Y_{i}^{o b s}\right)^{2}}
$$

Moriasi et al. (2007) evaluated the literature regarding model performance criteria and concluded that PBIAS findings of $<55 \%$ were adequate for sediment models.

\section{RESULTS \\ TreatMent EFFECTS}

The sediment trap data indicated that the control treatment was the most erosive, while the seed, mulch, and two slash treatments provided significant erosion control (table 1). As expected, each model indicated that treatments that increased ground cover decreased soil erosion. For all models, the most erosive treatment was the control, followed generally by the seed, slash, and mulch treatments. Depending on the erosion model, the slash and mulch treatments are juxtaposed with regard to effectiveness (table 1).

The control treatment represents the minimum level of BMP recommended for skid trails (Aust and Blinn, 2004), yet this minimum level still produces $5 \times$ the erosion of the seed treatment and $9 \times$ to $>40 \times$ the erosion of the mulch and slash treatments. Although successional patterns of natural vegetation can also ameliorate the bare soil conditions of the control, the bladed skid trails are a relatively harsh seeding environment due to the removal of the topsoil and trafficking. Christopher and Visser (2007) examined 60 closed harvesting sites and found that many skid trails were still actively eroding eight years after closure. Relative to the control, the remaining BMPs had a positive effect. Of these, the seed treatment was least effective even though lime, fertilizer, and multiple applications were used. Our data indicate that the simple addition of straw mulch to the seed treatment provided significant benefits. The mulch provides immediate cover, and the mulch treatments favored the establishment of the grass seed. We currently see similar practices used on skid trails near stream crossings or on steep sites, but this practice could be beneficial for additional areas. The hardwood and pine slash treatments were similarly effective in erosion control, and they potentially have four advantages relative to the

Table 1. Average erosion estimates for each treatment collected by sediment traps and predicted by three soil erosion models. Treatment values within a

\begin{tabular}{|c|c|c|c|c|c|c|c|}
\hline \multirow[b]{2}{*}{ Treatment } & \multirow{2}{*}{$\begin{array}{c}\text { Sediment Trap } \\
\text { (tonnes } \\
\text { ha }^{-1} \text { year }^{-1} \text { ) }\end{array}$} & \multicolumn{2}{|c|}{ USLE-Forest } & \multicolumn{2}{|c|}{ RUSLE2 } & \multicolumn{2}{|c|}{ WEPP-Road } \\
\hline & & $\begin{array}{c}\text { (tonnes } \\
\left.\text { ha }^{-1} \text { year }^{-1}\right)\end{array}$ & $\begin{array}{c}\text { PBIAS } \\
(\%)\end{array}$ & $\begin{array}{c}\text { (tonnes } \\
\left.\text { ha }^{-1} \text { year }^{-1}\right)\end{array}$ & $\begin{array}{c}\text { PBIAS } \\
(\%)\end{array}$ & $\begin{array}{c}\text { (tonnes } \\
\text { ha }^{-1} \text { year }^{-1} \text { ) }\end{array}$ & $\begin{array}{c}\text { PBIAS } \\
(\%)\end{array}$ \\
\hline Control & $137.7 \mathrm{a}$ & $63.1 \mathrm{a}$ & 53.67 & $148.4 \mathrm{a}$ & 7.78 & $18.3 \mathrm{a}$ & $86.71 *$ \\
\hline Seed & $31.5 \mathrm{~b}$ & $44.9 \mathrm{a}$ & 2.22 & $15.6 \mathrm{~b}$ & 50.48 & $12.0 \mathrm{a}$ & $61.90 *$ \\
\hline Hardwood slash & $8.9 \mathrm{bc}$ & $4.3 \mathrm{~b}$ & 23.25 & $17.5 \mathrm{~b}$ & $96.6^{*}$ & $2.0 \mathrm{~b}$ & $77.53 *$ \\
\hline Pine slash & $5.9 \mathrm{c}$ & $1.6 \mathrm{c}$ & $72.89 *$ & $15.5 \mathrm{~b}$ & $162.71 *$ & $2.6 \mathrm{~b}$ & $55.93 *$ \\
\hline Mulch & $3.0 \mathrm{c}$ & $3.2 \mathrm{~b}$ & 6.67 & $3.8 \mathrm{c}$ & 26.67 & $0.8 \mathrm{c}$ & $73.33 *$ \\
\hline
\end{tabular}
column followed by the same letter are not significantly different at $\alpha=0.05$. An asterisk (*) indicates a percent bias that was judged to be unacceptable. 
mulch treatments. Both slash treatments have a longer life expectancy than the straw mulch. If grass seed did not become established due to harsh weather and the straw decomposed, then the slash treatments would be advantageous. Another advantage of the slash treatments is that they immediately close the trail to traffic. Christopher and Visser (2007) found that unauthorized four-wheeler access was a primary cause of BMP failure on water barred and seeded skid trails. The slash restricts such traffic almost immediately. Third, the slash treatments may be less costly than the seed or mulch treatments, assuming that the slash is hauled onto the trails as the skidders travel back to get the next load of wood. Sawyers et al. (2012) ranked the relative costs of similar treatments on overland skid trails as lowest for slash and highest for mulch, fertilizer, lime, and seed treatments. However, if the slash transport is not completed as part of the harvest, then the mulch treatment becomes cheaper than the slash. Finally, both slash treatments offer the potential to add both organic material and nutrients to the bladed skid trail (Scott and Dean, 2006), which speculatively could partially ameliorate the removal of topsoil during construction.

\section{Model ACCURACY AND APPLICABILITY}

We compared all model erosion predictions to the sediment trap data (fig. 1). All three models correctly ranked the control, seeded, and hardwood slash treatments in order of erosion. The RUSLE and WEPP models also correctly ranked the mulch treatment as producing the least erosion (table 1). Overall, for the purpose of evaluating erosion hazards, all three models performed at levels that could be useful to land managers for hazard evaluation or BMP inspections. However, comparison of the sediment trap and modeled erosion rates indicated that USLE-Forest ranged from $0.9 \times$ to $2.2 \times$, RUSLE2 ranged from $0.4 \times$ to $2 \times$, and WEPP-Road ranged from $2.3 \times$ to $7.5 \times$. In terms of model PBIAS, no model provided acceptable levels with regard to the pine slash treatments. However, the USLEForest PBIAS values were acceptable for all other treatments. The PBIAS values for WEPP-Road were higher than acceptable for all treatments, and the RUSLE2 PBIAS values were acceptable for the control, mulch, and seed treatments. USLE-Forest probably performed the best with regard to PBIAS for several reasons. USLE-Forest has cover values that were specifically developed for forest applications. RUSLE2, which is a modification of the original USLE, has not been modified to the same degree for forest applications. More specifically, the RUSLE2 PBIAS values were greater for treatments that were most directly related to forest cover, e.g., the slash treatments. WEPP has been used successfully in many locales to predict erosion, yet WEPP-Road is a newer application with relatively few options for road characterization. The PBIAS findings indicate that the WEPP-Road options are not adequately calibrated relative to bladed skid trail treatments in the southeastern U.S. This problem has been a topic of discussion during three recent annual meetings of the Southern Group of State Foresters (William Lakel, personal communication).
The erosion model estimates were transformed with natural logarithms. The transformed model data formed a significant linear relationship with the transformed actual erosion data. All erosion models had correlation coefficients (r) above 0.85 . The untransformed data were used to calculate the NSE statistic, and USLE-Forest, RUSLE2, and WEPP-Road had NSE values of 0.55, 0.86, and -0.10 , respectively (figs. 4 through 6), implying that USLE-Forest and RUSLE2 compared favorably with the actual erosion data while the WEPP-Road erosion predictions were unacceptable.

USLE-Forest had the least strong linear relationship with the sediment trap data; however, it performed similarly to RUSLE2. The estimated relationship was $y=$ $0.85+0.81 x$, where $y$ is the natural $\log$ of the sediment trap erosion rates, and $x$ is the natural $\log$ of the USLE-Forest estimates. This linear relationship had an $\mathrm{R}^{2}$ of 0.75 and an $\mathrm{r}$ of 0.87 (fig. 4). RUSLE2 had the second best linear relationship when compared to the log transformed actual erosion data. The estimated relationship was $y=-0.53+$ $1.07 x$, where $y$ is the natural log of the sediment trap erosion rates, and $x$ is the natural log of the RUSLE2 estimates. This linear relationship had an $\mathrm{R}^{2}$ of 0.80 and an $\mathrm{r}$ of 0.89 (fig. 5). Overall, WEPP-Road had the best estimated linear relationship of $y=1.12+1.10 x$, where $y$ is the natural $\log$ of the sediment trap measured erosion rates, and $x$ is the natural $\log$ of the WEPP-Road estimates. This linear relationship had an $\mathrm{R}^{2}$ of 0.83 and an $\mathrm{r}$ of 0.91 (fig. 6).

WEPP-Road had the highest average magnitude of error at 30.3 tonnes ha $^{-1}$ year $^{-1}$, where the magnitude of error is calculated as the absolute value of the difference between the model predictions and the sediment trap rates. WEPPRoad tended to underpredict erosion, and the underpredictions were of greater magnitude for the control treatment. The ratio of sediment trap erosion versus WEPP-Road prediction was $7.5 \times$ for the control treatment. The WEPPRoad estimates were nearer to the sediment trap measurements when erosion rates were less, as in the case of the slash and mulch treatments, indicating that WEPPRoad is more suitable for these site conditions. The NSE statistic was recalculated for WEPP-Road with the control treatment data removed, and the NSE improved to 0.77 . Like WEPP-Road, the USLE-Forest estimates were more accurate when the sediment trap erosion rates were minimal. USLE-Forest also tended to underpredict when erosion rates were high (control), but not to the extent that WEPP-Road did. The most extreme difference in the model predictions and sediment trap results was 116.2 tonnes $\mathrm{ha}^{-1}$ year $^{-1}$, and USLE-Forest had an average magnitude of error of 20.1 tonnes ha $^{-1}$ year $^{-1}$.

RUSLE2 had the highest NSE statistic (0.86), indicating that the model predictions were the closest to the actual measured erosion. Overall, RUSLE2 did not consistently over- or underpredict erosion rates. As with the other models, the largest difference in model predictions compared to the sediment trap data was on the highly erosive treatments, i.e., the control, and the smallest difference was on treatments with minimal erosion, i.e., the slash and mulch treatments. Overall, the average magnitude of error was 14.0 tonnes ha $^{-1}$ year $^{-1}$. 
USLE - Forest Log vs Actual Erosion Data Log

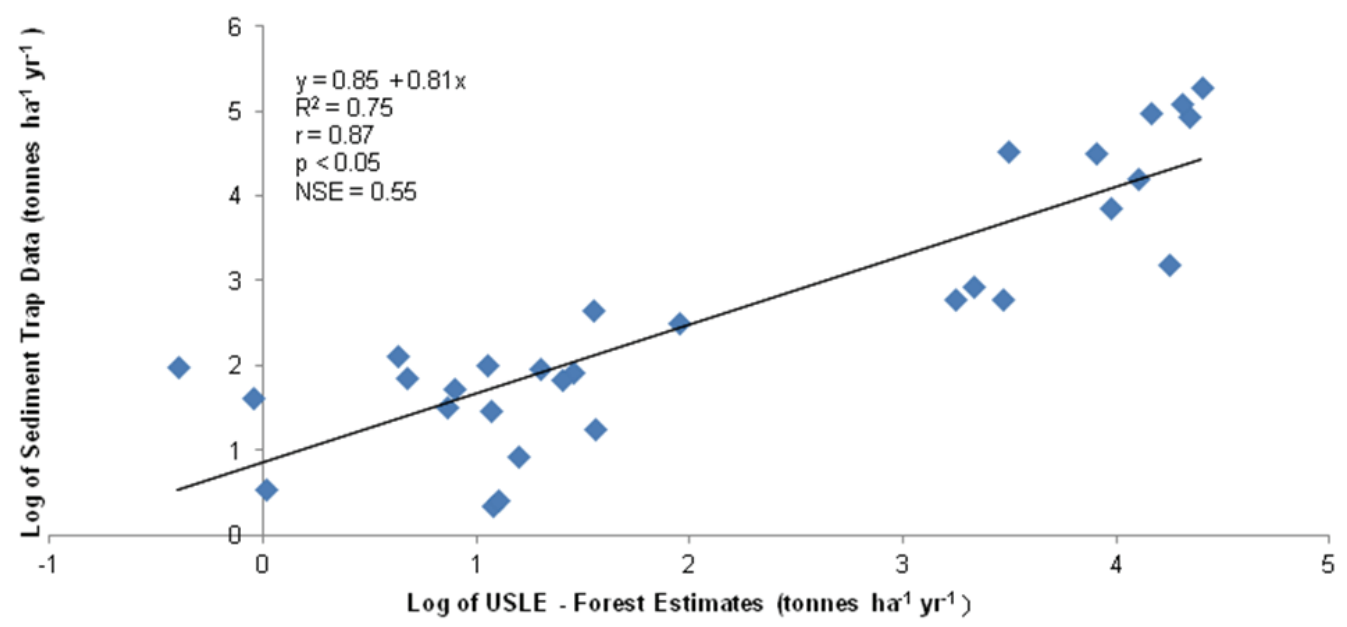

Figure 4. Linear relationship found between USLE-Forest estimates and the sediment trap erosion rates. In the reported equation, $y$ represents the logarithm transformed sediment trap results, and $x$ represents the logarithm transformed USLE-Forest results.

RUSLE2 Log vs Actual Erosion Data Log

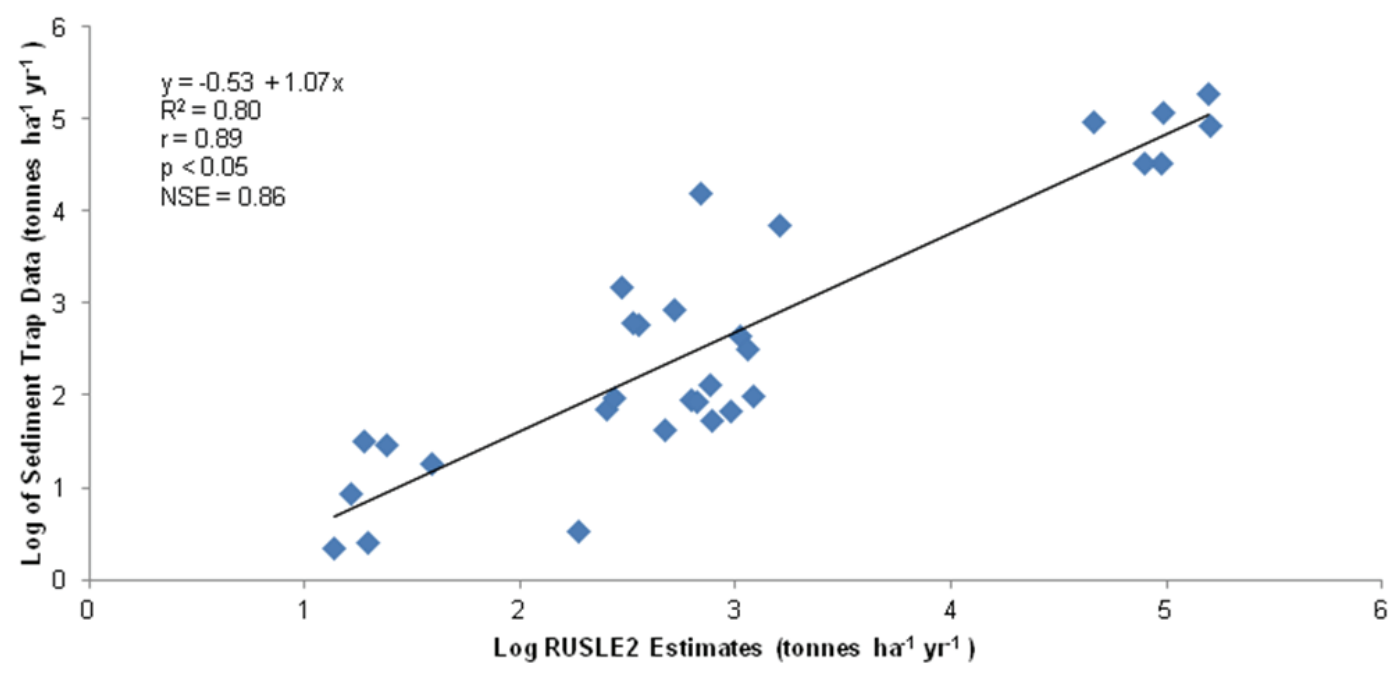

Figure 5. Linear relationship found between RUSLE2 estimates and the sediment trap erosion rates. In the reported equation, $y$ represents the logarithm transformed sediment trap results, and $x$ represents the logarithm transformed RUSLE2 results.

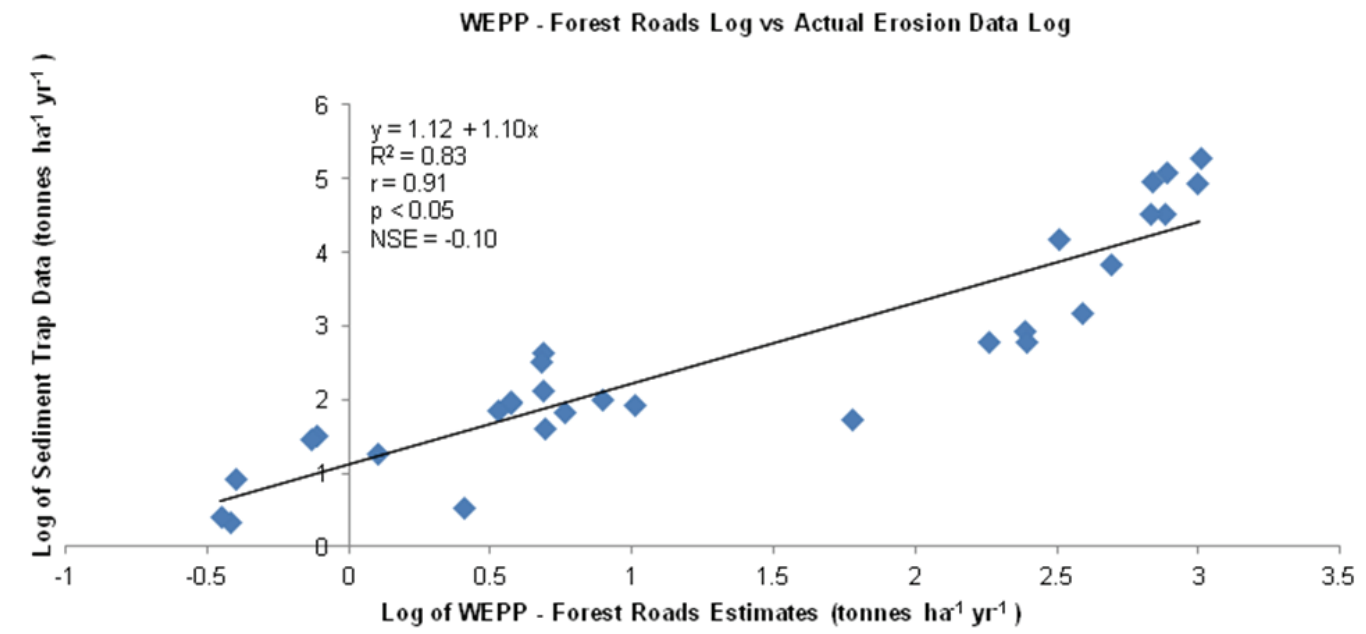

Figure 6. Linear relationship found between WEPP-Road estimates and the sediment trap erosion rates. In the reported equation, $y$ represents the logarithm transformed sediment trap results, and $x$ represents the logarithm transformed WEPP-Road results. 


\section{DisCUSSION}

Our results indicated that cover provided by vegetation, mulch, or slash were crucial for minimizing erosion and that the models appear to have different levels of utility depending on the intended use. Similar results have been found for the use of seed and mulch on wildfire rehabilitations (Groen and Woods, 2008; Dodson and Peterson, 2010) and straw mulch for erosion control at construction sites (Faucette et al., 2007). Grusheky et al. (2009) evaluated erosion control from skid trails and found that straw mats, similar to our mulch treatment, provided good erosion control. The studies of both McGreer (1981) and Rivenbark and Jackson (2004) support our findings regarding the use of slash for erosion control. Personal observations also indicate that slash is commonly used by loggers and is generally supported in BMP manuals (Aust and Blinn, 2004). Although several studies (Megahan and Kidd, 1972; Bilby et al., 1989; Briggs et al., 1998; Sidle et al., 2004) have speculatively supported the use of slash for skid trail closure, our data are the only data of which we are aware that quantified the benefits of slash on bladed skid trails in the eastern U.S.

USLE-Forest is a widely used erosion model for a wide variety of sites and management conditions (Brooks et al., 2003). The model is simple to learn and apply, with a relatively small learning curve. USLE-Forest is especially useful for field comparisons (Christopher and Visser, 2007). Assessments of erosion can be made quickly and simply with little more than the USLE-Forest manual, as compared to both the WEPP-Road and RUSLE2 modeling computations, which typically require computer access. The USLE-Forest model includes the contributions of individual variables and their relative significance to erosion rates. It is easy to understand the importance of the factors for any given site and management. However, there are some disadvantages to using USLE-Forest. The model provides long-term average annual erosion rates (tonnes ha ${ }^{1}$ year $^{-1}$ ) and is not appropriate for shorter time periods, nor does USLE-Forest estimate sediment deposition. Based on the NSE and PBIAS values, USLE-Forest appears to be most appropriate as a methodology for ranking BMP treatments for bladed skid trails or as a teaching tool that allows intended users to compare treatments in the field. Christopher and Visser (2007), Tiwari et al. (2000), and Croke and Nethery (2006) similarly support the use of the USLE and its modifications for ranking or comparison of BMPs.

Compared to USLE-Forest, RUSLE2 requires fewer field measurements. RUSLE2 is a computer package and offers databases that allow the user to download a variety of climate and management files. RUSLE2 was originally developed for agricultural purposes; therefore, many management files within the model are for cropland. However, the model allows creation of management files for specific conditions not within the database, thus increasing model applicability for a variety of land management regimes. Initial creation of management files can be time-consuming and tedious, but the created files can be used repeatedly thereafter. There are also databases of climate and soil files for most of the U.S. RUSLE2 allows evaluation of multiple management regimes on each hillslope, allowing land managers to examine the effects of combinations of management regimes. Due to its complexity, RUSLE2 allows users to simulate watersheds containing multiple hillslopes. Subsequently, RUSLE2 can model the erosion from each hillslope and predict the erosion from the watershed. RUSLE2 can also estimate sediment deposition on concave slopes at dense vegetation strips, terrace channels, and in sediment basins, which is a feature that USLE-Forest does not provide. RUSLE2 can be adjusted to vary the rainfall and runoff factor $(R)$ throughout the year. Monthly values can be evaluated to determine seasons that are most prone to erosion. Today, smaller computing packages facilitate use of the software.

Since RUSLE2 is a computer-based erosion model, it may not be as field expedient as USLE-Forest. Initially, there may be more time involved in RUSLE2 estimates due to the creation of management files. However, once the files have been created, they can be used quickly and easily in the future. Site factor and management influence can be manipulated with RUSLE2 through climate, soils, and management file selections, but the effects are more obscure than with USLE-Forest. USLE-Forest has advantages for those who are learning about the processes behind erosion, while RUSLE2 assumes this understanding. Tiwari et al. (2000) also emphasized that the complexity of RUSLE2 may limit its utility in nonresearch applications.

WEPP-Road, another computer-based model, is more similar to RUSLE2 than to USLE-Forest based on the user interaction with the model. Numerous researchers have found that WEPP can be used to accurately predict erosion. Examples include agricultural operations in Australia ( $\mathrm{Yu}$ and Rosewell, 2001), India (Pandey et al., 2008), and forest roads in Australia (Forsyth et al., 2006). Grace (2005b) evaluated the performance of WEPP on cut and fillslopes in the southern Appalachian region. He found that WEPP adequately described erosion across three levels of control, including a bare soil treatment and two vegetation treatments. Risse et al. (1993) evaluated the USLE, using the same dataset used by Tiwari et al. (2000), and concluded that the USLE performed adequately. They found that the model tended to overpredict small values and underpredict larger values, but on a consistent basis the model neither overpredicted nor underpredicted.

However, there are also instances where researchers have failed to find satisfactory agreement between WEPP predictions and actual erosion data. Reyes et al. (2003) found that neither RUSLE nor WEPP accurately predicted erosion for agricultural sites in North Carolina. Turton et al. (2005) found that WEPP underestimated erosion by approximately $50 \%$ for forest roads in the Ouachita Mountains. Tiwari et al. (2000) produced one of the few other studies that compared USLE, RUSLE, and WEPP. The models were evaluated based on data from 20 locations and more than 1,600 plot years of data. Results indicated that the USLE performed the best, followed by RUSLE and then WEPP. WEPP had an NSE statistic of 0.71, which is much higher that what was found in this study, indicating that there was less variability in the dataset used by Tiwari 
et al. (2000). Their dataset, however, was more applicable for use in USLE and RUSLE because these models used locally derived empirical erodibility parameters, while WEPP calculated parameters based on soil properties. Tiwari et al. (2000) also evaluated sites that were primarily influenced by agricultural practices and where the erosion rates were not as great, with the highest being 89 tonnes ha $^{-1}$.

WEPP-Road shares many of the advantages of RUSLE2. WEPP-Road offers databases of management files, soil files, and climate files that cover a wide geographic area and encompasses many different management regimes. WEPP-Road includes many management files that are specific to forest operations. As with RUSLE2, if a particular situation is not covered by a database management file, a new file can be created. Soil files and climate files can also be altered. WEPP-Road also allows the use of multiple management conditions per hillslope. Unlike USLE-Forest or RUSLE2, WEPP-Road provides monthly estimates of erosion. This is very beneficial for planning because the model indicates times of the year when additional measures should be taken to reduce erosion. RUSLE2 also provides this, but RUSLE2 shows monthly rainfall and runoff factor $(R)$ values rather than monthly erosion rates. Similar to RUSLE2, WEPPRoad can also estimate deposition on concave slopes, an advantage over USLE-Forest.

In this study, WEPP-Road had the best overall linear relationship with the sediment trap data $(r=0.9133)$ but the worst NSE statistic $(-0.10)$. This low NSE was a result of the model drastically underpredicting erosion rates on the control treatment. This could be a result of WEPP-Road being prone to underestimating high values (Tiwari et al., 2000) or that the management file, "Forest Bladed Road," is not appropriate for bladed skid trails. When the data for the control treatment were removed from the model efficiency calculation, the NSE statistic rose to 0.77 , indicating that WEPP-Road is more accurate when erosion rates are lower. USLE-Forest and RUSLE2 performed similarly to one another, with RUSLE2 having a slightly better $r$ value and a higher NSE statistic. RUSLE2 was better able to predict values on the control treatment, indicating that it may be more suitable for bladed skid trails. Moore et al. (2007) evaluated WEPP for erosion control on construction sites and found that WEPP could accurately predict erosion with considerable manipulation of parameters. This is perhaps the greatest strength and weakness of WEPP; it is flexible so that parameters can be manipulated, but the existing parameters may not be calibrated for a particular intent.

\section{Conclusions}

This study was designed to evaluate the accuracy of three common erosion models for predicting BMP effectiveness on bladed skid trails. All three models performed adequately in the context of ranking treatments in approximate order for hazard rating. The models ranked the control as the most erosive treatment, showing that it would not be suitable for many areas. All three models indicated that erosion rates decreased as cover increased on bladed trails. However, with regard to NSE, the USLEForest and RUSLE2 models performed adequately, while the WEPP-Road model was not adequate. PBIAS values also indicate that the USLE-Forest and RUSLE2 models were adequate, while WEPP-Road was not adequate.

Overall, the sediment trap data and the erosion models clearly indicate that any BMP treatment is preferable to the control with regard to erosion. The sediment trap data provided general support for using slash or mulch rather than the seed treatment. All models indicated that the control treatment was the least effective erosion control technique and had unacceptably high erosion rates, which may increase the likelihood of sediment being transported to waterways. Water bars alone were not adequate to prevent erosion and may not be sufficient for sediment control. If water bars are used without additional measures, they should be spaced and designed to route the runoff over litter layers to filter sediment.

Both USLE-Forest and WEPP-Road ranked the seed treatment as the fourth most effective treatment, while RUSLE2 ranked it as the second most effective. Overall, the seed treatment was effective at reducing erosion when compared to the control.

The pine slash, hardwood slash, and mulch treatments were ranked as most effective at reducing erosion. These treatments are most suitable for improved erosion control and protection of water quality. The erosion control provided by the slash and mulch treatments was immediate, occurring upon application. The erosion control of the slash treatments is also likely to be persistent, lasting several years. The slash treatments may also be advantageous for restricting unauthorized traffic access.

Each erosion model performed well when compared to the erosion rates determined from sediment traps. Linear relationships were fit to all erosion models, and WEPPRoad had higher $\mathrm{R}^{2}(0.83)$ and $\mathrm{r}(0.91)$ values but also had a poor NSE statistic (-0.10). RUSLE2, with an $\mathrm{R}^{2}$ of 0.80 , an $r$ of 0.89 , had the best NSE statistic (0.86). USLE-Forest had an $\mathrm{R}^{2}$ of 0.75 , an $\mathrm{r}$ of 0.87 , and an NSE statistic of 0.55 . Based on linear regression diagnostics and NSE values, RUSLE2 performed the best, USLE-Forest the poorest, and WEPP was intermediate.

The results show that all three models overpredicted as compared to lower values of sediment trap erosion and underpredicted where sediment trap values were greater, with WEPP-Road drastically underpredicting the control treatment. The management file "Forest Bladed Road" is not suitable for a wide range of skid trails, and additional management files more specific to bladed skid trails should be developed to enhance WEPP-Road's utility. Although WEPP-Road had unsatisfactory performance in this study, the potential of the model for improvement in forestry applications is greater than that of the older USLE-Forest or the more agriculture-related RUSLE2. The applicability of WEPP-Road will hopefully be improved by adding selections for roads, surfacing, cover, and enhancing the soil selections. 


\section{REFERENCES}

Amore, E., C. Modica, M. A. Nearing, and V. Santoro. 2004. Scale effect in USLE and WEPP application for soil erosion computation from three Sicilian basins. J. Hydrol. 293: 100-114.

Anderson, C. J., and B. G. Lockaby. 2011. Research gaps related to forest management and stream sediment in the United States. Environ. Mgmt. 47(2): 303-313.

Aust, W. M., and C. R. Blinn. 2004. Forestry best management practices for timber harvesting and site preparation in the eastern United States: An overview of water quality and productivity research during the past 20 years (1982-2002). Water, Air, and Soil Pollution: Focus 4(1): 5-36.

Barber, B. L., and D. H. Van Lear. 1984. Weight loss and nutrient dynamics in decomposing woody loblolly pine logging slash. SSSA J. 48(4): 906-910.

Bilby, R. E., K. Sullivan, and S. H. Duncan. 1989. The generation and fate of road-surface sediment in forested watersheds in southwestern Washington. Forest Sci. 35(2): 453-468.

Bolding, M. C., S. M. Barrett, J. F. Munsell, and M. C. Groover. 2010. Characteristics of Virginia's logging businesses in a changing timber market. Forest Products J. 60(1): 86-93.

Briggs, R. D., J. Cormier, and A. Kimball. 1998. Compliance with forestry best management practices in Maine. Northern J. Applied Forestry 15(2): 57-68.

Brooks, K. N., P. F. Ffolliott, H. M. Gregersen, and L. F. DeBano. 2003. Hydrology and the Management of Watersheds. 3rd ed. Ames, Iowa: Iowa State Press.

Cecilo, R. A., R. G. Rodriguez, L. G. N. Baena, F. G. Olivera, F. F. Pruski, A. M. Speohan, and J. M. A. Silva. 2004. Analysis of the RUSLE and WEPP models for a small watershed located in Vicosa, Minas Gerais State, Brazil. Paper No. 658. In Proc. 13th ISCO Conf. International Soil Conservation Organization.

Christopher, E. A., and R. Visser. 2007. A methodology for evaluating post harvest erosion risk for the protection of water quality. New Zealand J. Forestry 52(2): 20-25.

Croke, J., and M. Nethery. 2006. Modelling runoff and soil erosion in logged forests: Scope and application of some existing models. Catena 67(1): 35-49.

Dissmeyer, G. E., and G. R. Foster. 1984. A guide for predicting sheet and rill erosion on forestland. General Tech. Publ. R8-TP 6. Washington, D.C.: USDA Forest Service.

Dodson, E. K., and D. W. Peterson. 2010. Mulching effects on vegetation recovery following high severity wildfire in northcentral Washington State, USA. Forest Ecol. and Mgmt. 260(10): 1816-1823.

Dun, S., J. Q. Wu, W. J. Elliot, P. R. Robichaud, D. C. Flanagan, J. R. Frankenberger, R. E. Brown, and A. C. Xu. 2009. Adapting the Water Erosion Prediction Project (WEPP) model for forest applications. J. Hydrol. 366: 46-54.

Elliot, W. J. 2004. WEPP internet interfaces for forest erosion prediction. J. American Water Resources Assoc. 40(2): 299-309.

Elliot, W. J., R. B. Foltz, and C. H. Luce. 1995. Validation of Water Erosion Prediction Project (WEPP) model for low-volume forest roads. In Proc. 6th Intl. Conf. on Low-Volume Forest Roads, 178186. Washington, D.C.; National Academy Press.

Elliot, W. J., D. E. Hall, and S. R. Graves. 1999. Predicting sedimentation from forest roads. J. Forestry 97(8): 23-29.

Faucette, L. B., J. Governo, C. F. Jordan, B. G. Lockaby, H. F. Carino, and R. Governo. 2007. Erosion control and storm water quality from straw with PAM, mulch, and compost blankets of varying particle sizes. J. Soil and Water Cons. 62(6): 404-423.

Forsyth, A. R., K. A. Bubb, and M. E. Cox. 2006. Runoff, sediment loss, and water quality from forest roads in a southeast Queensland coastal plain Pinus plantation. Forest Ecol. and Mgmt. 221(1-3): 194-206.

Foster, G. R., T. E. Toy, and K. G. Renard. 2003. Comparison of the
USLE, RUSLE1.06, and RUSLE2 for application to highly disturbed lands. In Proc. First Interagency Conf. on Research in the Watersheds, 154-160. Tucson, Ariz.: USDA-ARS Southwest Watershed Research Center.

Fu, B., L. T. H. Newham, and C. E. Ramos-Scharron. 2010. A review of surface erosion and sediment delivery models for unsealed roads. Environ. Modelling and Software 25(1): 1-14.

Garland, J. J. 1997. Designated skid trails minimize soil compaction. The Woodland Workbook EC 1110. Corvallis, Ore.: Oregon State University Extension Service.

Grace, J. M., III. 2002. Overview of best management practices related to forest roads: The southern states. ASABE Paper No. 025013. St. Joseph, Mich.: ASABE.

Grace, J. M., III. 2005a. Forest operations and water quality in the south. Trans. ASAE 48(2): 871-880.

Grace, J. M., III. 2005b. Application of WEPP to a southern Appalachian forest road. ASABE Paper No. 052016. St. Joseph, Mich.: ASABE.

Groen, A. H., and S. W. Woods. 2008. Effectiveness of aerial seeding and straw mulch for reducing post-fire erosion, northwestern Montana, USA. Intl. J. Wildland Fire 17(5): 559-571.

Grushecky, S. T., B. D. Spong, D. W. McGill, and J. W. Edwards. 2009. Reducing sediments from skid roads in West Virginia using fiber mats. Northern J. Applied Forestry 26(3): 118-121.

Hood, S. M., S. M. Zedaker, W. M. Aust, and D. W. Smith. 2002. Soil erosion in Appalachian hardwoods: Using the Universal Soil Loss Equation (USLE) to compare the impacts of different harvest methods. Northern J. Applied Forestry 19(2): 53-58.

Ice, G. G., E. Schilling, and J. Vowell. 2010. Trends for forestry best management practices implementation. J. Forestry 108(6): 267273.

Jackson, S. M., T. S. Fredricksen, and J. R. Malcolm. 2001. Area disturbed and residual stand damage following logging in a Bolivian tropical forest. Forest Ecol. and Mgmt. 166(1-3): 271283.

Kochenderfer, J. N. 1977. Area in skidroads, truck roads, and landings in the central Appalachians. J. Forestry 75(8): 507-508.

Kochenderfer, J. N., and J. D. Helvey. 1987. Using gravel to reduce soil losses from minimum-standard forest roads. J. Soil and Water Cons. 42(1): 46-50.

Laflen, J. M. D. C. Flanagan, and B. A. Engel. 2004. Soil erosion and sediment yield prediction accuracy using WEPP. J. American Water Resources Assoc. 40(2): 289-297.

McGreer, D. 1981. A study of erosion from skid trails in northern Idaho. In Measuring and Assessing the Effectiveness of Alternate Forest Management Practices on Water Quality, 1-9. Tech. Bulletin No. 353. Research Triangle Park, N.C.: National Council for Air and Stream Improvement, Inc.

Megahan, W. F., and W. J. Kidd. 1972. Effect of logging roads on sediment production rates in the Idaho Batholith. Research Paper INT-123. Ogden, Utah: USDA Forest Service, Intermountain Research Station.

Megahan, W. F., M. Wilson, and S. B. Monsen. 2001. Sediment production from granitic cutslopes on forest roads in Idaho, USA. Earth Surface Proc. and Landforms 26(2): 153-163.

Merritt, W. S., R. A. Letcher, and A. J. Jakeman. 2003. A review of erosion and sediment transport models. Environ. Modeling and Software 18(8-9): 761-779.

Moore, A. D., R. A. McLaughlin, H. Mitasova, and D. E. Line. 2007. Calibrating WEPP model parameters for erosion prediction on construction sites. Trans. ASABE 50(2): 507-516.

Moriasi, D. N., J. G. Arnold, M. W. Van Liew, R. L. Binger, R. D. Harmel, and T. L. Veith. 2007. Model evaluation guidelines for systematic quantifications of accuracy in watershed simulations. Trans. ASABE 50(3): 885-900.

Nash, J. E., and J. E. Sutcliffe. 1970. River flow forecasting through 
conceptual models: Part 1. A discussion of principles. J. Hydrol. 10(3): 282-290.

Neary, D. G., W. T. Swank, and H. Riekerk. 1989. An overview of nonpoint-source pollution in the southern United States. In Proc. Symp. Forested Wetlands of the United States, 1-7. D. Hook and R. Lea, eds. General Tech. Report SE-50. Washington, D.C.: USDA Forest Service.

NRCS. 2009. Web soil survey. Washington, D.C.: USDA Natural Resources Conservation Service. Available at: http://websoilsurvey.nrcs.usda.gov. Accessed 4 July 2011.

Onega, T. L., and W. G. Eickmeir. 1991. Woody detritus and decomposition kinetics in a southern temperate deciduous forest. Bull. Torrey Botanical Club 118(1): 52-57.

Pandey, A., V. M. Chowdary, B. C. Lal, and M. Billib. 2008. Runoff and sediment yield modeling from a small agricultural watershed in India using the WEPP model. J. Hydrol. 348(3-4): 305-319.

Patrick County. 2012. Climate. Stuart, Va.: Patrick County Administrative Offices. Available at: www.co.patrick.va.us/ demographics. Accessed 4 April 2012.

Renard, K. G., G. R. Foster, G. A. Weesies, and J. P. Porter. 1991. RUSLE: Revised Universal Soil Loss Equation. J. Soil and Water Cons. 46(1): 30-33.

Reyes, M. R., C. W. Raczkowski, G. A. Gayle, and G. B. Reddy. 2003. Technical note: Comparing the soil loss predictions of GLEAMS, RUSLE, EPIC, and WEPP. Trans. ASAE 47(2): 489493.

Rhee, H., J. L. Findley, and R. B. Foltz. 2004. Modeling erosion from unpaved forest roads at various levels of geometric detail using the WEPP model. Trans. ASAE 47(3): 961-968.

Rice, R. M., J. S. Rothacher, and W. F. Megahan. 1972. Erosional consequences of timber harvesting: An appraisal. In Proc. Watersheds Transition Symp., 321-329. Urbana, Ill.: American Water Resources Association.

Risse, L. M., M. A. Nearing, J. M. Laflen, and A. D. Nicks. 1993. Error assessment in the Universal Soil Loss Equation. SSSA J. 57(3): 825-833.

Rivenbark, B. L., and C. R. Jackson. 2004. Concentrated flow breakthroughs moving through silvicultural streamside management zones: Southeastern Piedmont, USA. J. American Water Resources Assoc. 40(4): 1043-1052.

Robichaud, P. R., and R. E. Brown. 2002. Silt fences: an economical technique for measuring hillslope erosion. General Tech. Report RMRS-GTR-94. Washington, D.C.: USDA Forest Service.

SAS. 2008. SAS/STAT 9.2 User's Guide: The GLM Procedure. Cary, N.C.: SAS Institute, Inc.

Sawyers, B. C., M. C. Bolding, W. M. Aust, and W. A. Lakel III. 2012. Effectiveness and implementation costs of overland skid trail closure techniques in the Virginia Piedmont. J. Soil and Water Cons. (in press).

Scott, D. A., and T. J. Dean. 2006. Energy tradeoffs between intensive biomass utilization, site productivity loss, and ameliorative treatments in loblolly pine plantations. Biomass and Bioenergy 30(12): 1001-1010.

Sheridan, G. J., P. J. Noske, R. K. Whipp, and N. Wijesinghe. 2006. The effect of truck traffic and road water content on sediment delivery from unpaved forest roads. Hydrol. Proc. 20(8): 16831699.
Sidle, R. C., S. Sasaki, M. Otsuki, S. Noguchi, and A. R. Nik. 2004. Sediment pathways in a tropical forest: Effects of logging roads and skid trails. Hydrol. Proc. 18(4): 703-720.

Swift, L. W., Jr. 1985. Forest road design to minimize erosion in the southern Appalachians. In Proc. Forestry and Water Quality: A Mid-South Symp., 141-151. B. G. Blackmon, ed. Monticello, Ark.: University of Arkansas.

Swift, L. W., Jr., and R. G. Burns. 1999. The three Rs of roads. J. Forestry 97(8): 40-44.

Tiwari, A. K., L. M. Risse, and M. A. Nearing. 2000. Evaluation of and WEPP and its comparison with USLE and RUSLE. Trans. ASAE 43(5): 1129-1135.

Toy, T. J., G. R. Foster, and K. G. Renard. 1999. RUSLE for mining, construction, and reclamation lands. J. Soil and Water Cons. 54(2): 462-467.

Turton, D. J., P. R. Busteed, and J. Nettles. 2005. Erosion from established forest road in the Ouachita Mountains. In Proc. 3rd Conf. Watershed Management to Meet Water Quality Standards and Emerging TMDLs, 101-109. ASABE Publication No. 701P0105. St. Joseph, Mich.: ASABE.

Tyner, J. S., D. C. Yoder, B. J. Chomicki, and A. Tyagi. 2011. A review of construction site best management practices for erosion control. Trans. ASABE 54(2): 441-450.

USEPA. 2003. Nonpoint-source pollution: The nation's largest water quality problem. Washington, D.C.: U.S. Environmental Protection Agency, Office of Water, Nonpoint-Source Control Branch. Available at: www.epa.gov/owow/nps/facts/point1.htm. Accessed 5 May 2009.

VDOF. 2011. Virginia's Forestry Best Management Practices for Water Quality: Technical Manual. 5th edition. Charlottesville, Va.: Virginia Department of Forestry.

Wade, C. R. 2010. Evaluation of best management practices for bladed skid trail erosion control and determination of erosion model accuracy and applicability. MS thesis. Blacksburg, Va.: Virginia Tech, Department of Forest Resources and Environmental Conservation.

Wade, C. R., W. M. Aust, and M. C. Bolding. 2010. Evaluation of bladed skid trail closure and cover BMPs for erosion control. In Proc. Council on Forest Engineering Annual Meeting. Corvallis, Ore.: Council on Forest Engineering.

Wade, C. R., W. M. Aust, M. C. Bolding, and W. A. Lakel III. 2011. Erosion control on bladed skid trails. In Proc. 16th Biennial Southern Silviculture Research Conf. Asheville, N.C.: USDA Forest Service, Southern Reserach Station.

Wade, C. R., M. C. Bolding, W. M. Aust, and W. A. Lakel III. 2012. Comparison of five erosion control techniques for bladed skid trails in Virginia. Southern J. Applied Forestry (in press).

Wischmeier, W. H., and D. D. Smith. 1965. Predicting Rainfall Erosion Losses from Cropland East of the Rocky Mountains. Agricultural Handbook 282. Washington, D.C.: USDA Agricultural Research Service.

Yoho, N. S. 1980. Forest management and sediment production in the south: A review. Southern J. Applied Forestry 4(1): 27-36.

Yu, B., and C. J. Roswell. 2001. Evaluation of WEPP for runoff and soil loss prediction at Gunnedah, NSW, Australia. Australian J. Soil Res. 39(5): 1131-1145. 